\title{
Impacts of an Ageing Population on Social Systems - Selected Issues
}

\author{
Ladislav Průša \\ Research Institute for Labour and Social Affairs, Dělnická 213/12, 17000 Prague 7, Czech Republic
}

\begin{abstract}
Population ageing impacts on all social systems. The aim of this paper is to characterise the impacts of an ageing population on the social services and healthcare systems in the Czech Republic. These are the systems that will be most affected by the growing number of people of post-productive age. For social services, an estimate of the evolution of the number of beneficiaries of care allowance up to 2030 was drawn up on the basis of an analysis of the evolution in the number of beneficiaries of this social benefit by sex, age and degree of dependency in the years 2007 to 2016; for healthcare, an estimate of health insurance companies' expected expenditure on healthcare was drawn up on the basis of an analysis of the evolution of spending on healthcare by health insurance companies, broken down by clients' sex and age. The calculations clearly show that both these systems are unprepared for tackling the consequences of population ageing, so the search should begin now for new solutions that would help ensure that both social services and healthcare continue to be provided to clients to the existing standard in the coming period.
\end{abstract}

Keywords: Social services, Healthcare, Population ageing, Care allowance, Gender differences, Healthcare System

\section{Introduction}

The Population Forecast of the Czech Republic up to 2100 was published in 2013 (Czech Statistical Office, 2013). That presented an opportunity to quantify and update the impacts the expected population developments will have on all social systems. While the impacts in the field of pension insurance have been long discussed within the Expert Commission on Pension Reform and quantifying these impacts is mainly a question of standard actuarial calculations, the impact of population ageing on social services or healthcare is a marginal topic: practically no attention has been paid to ways to influence demographic change through pro-natalist measures or active migration policy. The aim of this paper is therefore to quantify the impacts of demographic change on the Czech Republic's social services and healthcare systems and, in the light of the results, to outline suitable measures that would help ensure that both these systems are able to provide these services to at least the existing standard in the coming years.

\section{References Overview}

Very little attention has been paid in the specialist literature to the impact of population ageing on the Czech systems of social services and healthcare (Průša, 2015; Průša, 2017). From the perspective of social services, however, forecasts are based on out-of-date data from 2007-2009, so the data thus acquired do not fully reflect the current state of affairs, as the following years brought a change in the conditions for assessing the degree of dependency and an increase in the care allowance at its various levels, which will certainly also be reflected in changes in the structure of the population receiving this social benefit. Having up-to-date data on the care allowance drawdown structure by sex, age and degree of dependency in the years 2010 to 2016 therefore makes it possible to re-quantify the expected developments in the number of care allowance beneficiaries up to 2030 and, on this basis, to outline the need for social care services in this period.

\section{Methodology and Data}

The starting point for quantifying the expected impacts of population ageing on the need for social care services consists in data from the Ministry of Labour and Social Affairs (MoLSA) information system on the structure of care allowance beneficiaries by sex, age and degree of dependency for December of every calendar year from 2007 to 2016 with the exception of 2013, when problems linked to a change in the administrator of all the MoLSA information systems meant that the data for that year have not been consolidated yet; consequently, data for the closest available period - February

International Journal of Operations Management, vol. 1, issue 2, pp. 7-17, January 2021 
2014 - are used in place of the December 2013 data. The starting point for quantifying health insurance companies' expected expenditure consists in data from statistical health accounts on the magnitude of health insurance companies' expenditure on healthcare by age and sex in the period from 2000 to 2013; data for the following years were not taken into account in view of the change in the methodology for monitoring healthcare expenditure, as certain other expenditure, mainly on prevention and long-term social care, was included in spending on healthcare, unlike in the previous period.

\section{Results and Discussion}

\subsection{Characteristics of the Key Results of the Population Forecast of the CR up to 2100}

The population forecast contained low, intermediate and high scenarios. The intermediate forecast, which is viewed and presented as the most probable, was used for the subsequent calculations. The aim of the forecast is to outline the main aspects of the expected future population growth in the Czech Republic and to flag up changes in the population's age composition.

In the intermediate forecast, the total population size is set to fall constantly from as soon as 2019 , dropping to $7,712,000$ people in 2100, whereby:

- $\quad$ the number of live-born children will not increase in the following years: e.g. in 2033 there should be 78,249 children born and, after a slight increase in the 2070s, the number should fall to approx. 60,500 at the end of the century;

- the number of people over 65 years of age is set to rise constantly to reach 3,219,000 in 2057 and should then fall until the end of the period under scrutiny; their share of the total population should increase from $16.81 \%$ in 2015 to as much as $34.00 \%$ in 2059 , ending up at $32.53 \%$ in 2100 ;

- the number of people over 80 is set to increase until 2063, when it will reach 1,409,000; their share of the population should increase from $3.86 \%$ in 2015 to $15.54 \%$ in 2069 , before falling again to $15.37 \%$ in 2100 (see Chart $1)$.

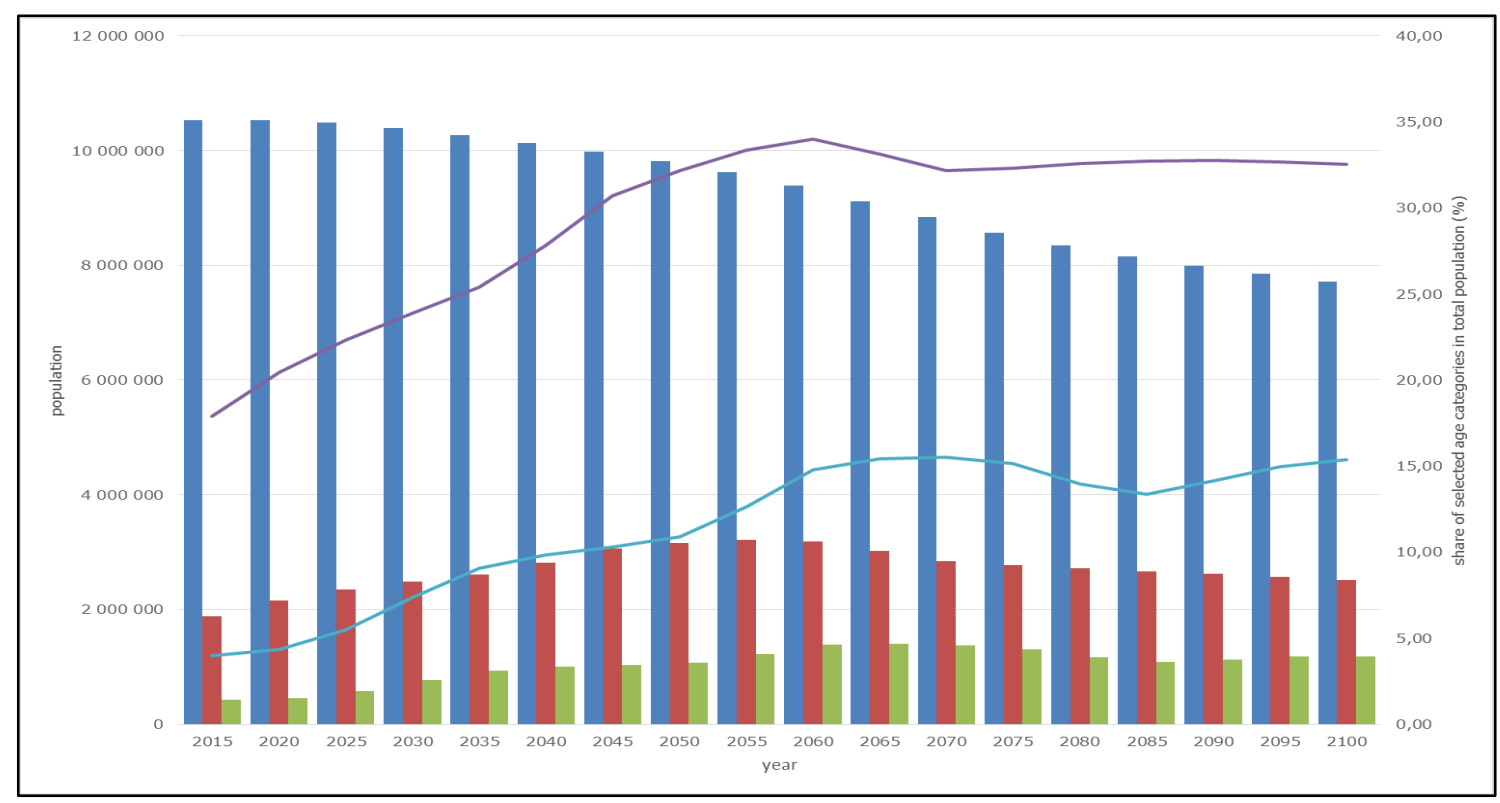

Figure 1: Evolution of the population size and selected categories of seniors up to 2100 (Source: Czech Statistical Office, 2013)

\subsection{Expected Impacts of Population Ageing on the Need for Social Care Services}

Quantification of the expected impacts of population ageing on the need for social care services can be based on data on the structure of care allowance beneficiaries by sex, age and degree of dependency, as found in the MoLSA information system. The first forecast of the need for social care services was drawn up in 2014 (Průša, 2015), using data on the 
structure of care allowance beneficiaries from the years 2007 to 2009. As the criteria for assessing degrees of dependency were changed in 2011, it is necessary to update the previously presented findings.

Throughout the period from 2011 the number of care allowance beneficiaries rose: there were 303,900 persons receiving this benefit in December 2011 and 348,800 in December 2016. There were significant changes in the structure of beneficiaries, with the share of persons collecting care allowance in the $1^{\text {st }}$ degree of dependency falling in that period from $35.8 \%$ to $30.7 \%$ and the share of beneficiaries in the $3^{\text {rd }}$ degree of dependency rising from $19.9 \%$ to $23.1 \%$ in the same period. From the perspective of forecasting the need for social care services for persons over the age of 60 , some of the most representative data are information on changes in the proportion of the total population of the given age category accounted for by care allowance beneficiaries in the various degrees of dependency, structured according to sex in fiveyear age intervals. Unlike in the previous forecast, data on the relative frequency of care allowance beneficiaries in the 0-17 and 18-59 age groups were processed for the first time, but the broad age interval makes it necessary to evaluate these data with considerable caution (see Table 1).

Table 1: Evolution of care allowance beneficiaries' share in the population of a given age group

\begin{tabular}{|c|c|c|c|c|c|c|c|c|c|c|c|}
\hline $\operatorname{sex}$ & $\begin{array}{l}\text { degree of } \\
\text { depend- } \\
\text { ency }\end{array}$ & age group & 2007 & 2011 & 2016 & sex & $\begin{array}{l}\text { degree of } \\
\text { depend- } \\
\text { ency }\end{array}$ & age group & 2007 & 2011 & 2016 \\
\hline \multirow{36}{*}{ 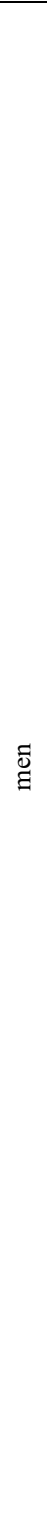 } & \multirow{9}{*}{ 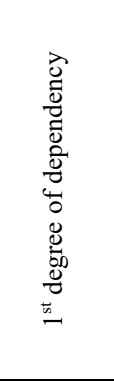 } & $0-17$ & 0.15 & 0.55 & 0.72 & \multirow{36}{*}{$\underset{\stackrel{D}{N}}{\grave{N}}$} & \multirow{9}{*}{ 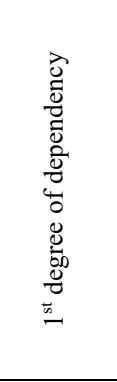 } & $0-17$ & 0.11 & 0.41 & 0.53 \\
\hline & & $18-59$ & 0.30 & 0.25 & 0.29 & & & $18-59$ & 0.27 & 0.23 & 0.26 \\
\hline & & $60-64$ & 1.00 & 0.82 & 0.87 & & & $60-64$ & 0.96 & 0.77 & 0.74 \\
\hline & & $65-69$ & 1.42 & 1.10 & 1.14 & & & $65-69$ & 1.68 & 1.25 & 1.18 \\
\hline & & $70-74$ & 2.16 & 1.59 & 1.49 & & & $70-74$ & 3.62 & 2.48 & 2.13 \\
\hline & & $75-79$ & 3.86 & 2.73 & 2.30 & & & $75-79$ & 7.85 & 5.76 & 4.51 \\
\hline & & $80-84$ & 8.91 & 5.53 & 4.56 & & & $80-84$ & 16.93 & 11.98 & 10.15 \\
\hline & & $85-89$ & 16.11 & 11.28 & 8.06 & & & $85-89$ & 24.80 & 18.52 & 14.88 \\
\hline & & $90+$ & 22.35 & 15.27 & 11.94 & & & $90+$ & 25.52 & 17.53 & 14.31 \\
\hline & \multirow{9}{*}{ 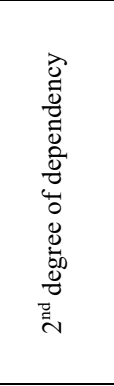 } & $0-17$ & 0.10 & 0.32 & 0.50 & & \multirow{9}{*}{ 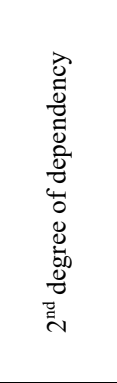 } & $0-17$ & 0.06 & 0.18 & 0.28 \\
\hline & & $18-59$ & 0.39 & 0.33 & 0.38 & & & $18-59$ & 0.30 & 0.27 & 0.30 \\
\hline & & $60-64$ & 0.92 & 0.86 & 1.02 & & & $60-64$ & 0.68 & 0.66 & 0.78 \\
\hline & & $65-69$ & 1.28 & 1.23 & 1.37 & & & $65-69$ & 1.07 & 0.98 & 1.13 \\
\hline & & $70-74$ & 1.96 & 1.72 & 1.88 & & & $70-74$ & 2.03 & 1.83 & 1.82 \\
\hline & & $75-79$ & 3.18 & 2.92 & 2.85 & & & $75-79$ & 4.51 & 4.00 & 3.84 \\
\hline & & $80-84$ & 6.31 & 5.47 & 5.36 & & & $80-84$ & 10.01 & 9.00 & 8.94 \\
\hline & & $85-89$ & 11.45 & 9.98 & 9.72 & & & $85-89$ & 17.25 & 15.51 & 16.00 \\
\hline & & $90+$ & 21.25 & 16.47 & 16.23 & & & $90+$ & 27.86 & 21.74 & 21.53 \\
\hline & \multirow{9}{*}{ 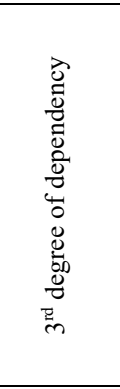 } & $0-17$ & 0.78 & 0.27 & 0.34 & & \multirow{9}{*}{ 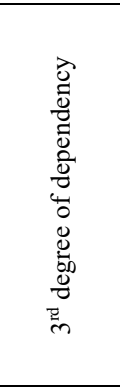 } & $0-17$ & 0.58 & 0.19 & 0.19 \\
\hline & & $18-59$ & 0.13 & 0.24 & 0.30 & & & $18-59$ & 0.10 & 0.19 & 0.23 \\
\hline & & $60-64$ & 0.27 & 0.48 & 0.65 & & & $60-64$ & 0.21 & 0.34 & 0.45 \\
\hline & & $65-69$ & 0.45 & 0.70 & 0.89 & & & $65-69$ & 0.38 & 0.51 & 0.66 \\
\hline & & $70-74$ & 0.74 & 1.00 & 1.36 & & & $70-74$ & 0.64 & 0.93 & 1.08 \\
\hline & & $75-79$ & 1.29 & 1.76 & 2.13 & & & $75-79$ & 1.44 & 2.11 & 2.24 \\
\hline & & $80-84$ & 2.34 & 3.26 & 4.04 & & & $80-84$ & 3.03 & 4.69 & 5.50 \\
\hline & & $85-89$ & 3.94 & 5.98 & 7.28 & & & $85-89$ & 6.02 & 9.62 & 10.90 \\
\hline & & $90+$ & 7.79 & 12.00 & 13.10 & & & $90+$ & 11.92 & 16.91 & 19.45 \\
\hline & \multirow{9}{*}{ 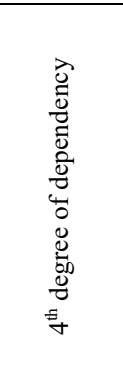 } & $0-17$ & 0.22 & 0.33 & 0.28 & & \multirow{9}{*}{ 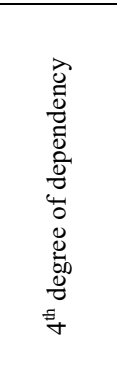 } & $0-17$ & 0.16 & 0.21 & 0.18 \\
\hline & & $18-59$ & 0.08 & 0.15 & 0.19 & & & $18-59$ & 0.07 & 0.12 & 0.15 \\
\hline & & $60-64$ & 0.13 & 0.20 & 0.26 & & & $60-64$ & 0.10 & 0.18 & 0.21 \\
\hline & & $65-69$ & 0.23 & 0.31 & 0.40 & & & $65-69$ & 0.16 & 0.25 & 0.28 \\
\hline & & $70-74$ & 0.40 & 0.55 & 0.61 & & & $70-74$ & 0.36 & 0.50 & 0.51 \\
\hline & & $75-79$ & 0.71 & 0.94 & 1.05 & & & $75-79$ & 0.78 & 1.12 & 1.21 \\
\hline & & $80-84$ & 1.22 & 1.61 & 1.94 & & & $80-84$ & 1.92 & 2.70 & 2.94 \\
\hline & & $85-89$ & 2.23 & 2.86 & 3.37 & & & $85-89$ & 3.74 & 5.84 & 6.39 \\
\hline & & $90+$ & 4.88 & 5.30 & 6.20 & & & $90+$ & 8.96 & 13.21 & 13.64 \\
\hline
\end{tabular}

Source: own calculations 
Both the nature of social policy and the need for social services are influenced by four basic factors:

- demographic developments;

- socio-economic factors;

- socio-political determinants;

- international aspects (Průša, 1996).

From this point of view it is necessary to keep in mind the following facts when forecasting the need for social care services:

- population ageing and the consequences of this trend (from the social services' perspective, the period of life in which people are dependent on help from others gets longer);

- the transfer of the quality of life during productive age into the period when people become increasingly dependent on help from others and the resultant growing cost of the provided care;

- the transformation and humanisation of residential social services;

- the concept of social services as services in the public interest;

- the quest for the optimum provision for social needs in humane, technical, technological and thus also economic terms;

- the increasing intertwining and coordination of social and healthcare services at regional level.

However, the effects of other factors, some of which are very hard to quantify and were therefore not taken into account, should not be overlooked. These include:

- changes in the standard of health of the population;

- evolution of the epidemiological situation;

- possible changes in the way care for old and disabled citizens is organised and structured (e.g. the transformation of old people's homes into nursing homes and their possible incorporation into the healthcare department).

The forecast of the need for social care services is grounded in existing law, but it is a reasonable expectation that, in the interests of making the entire system of social care provision and funding more effective, there will be significant changes in the system for assessing seniors' and disabled persons' degree of dependency in the coming period (e.g. greater differentiation of care needs) and in the social services funding system (most notably, abolition of the ceiling for clients' payments for provided social services, thus eliminating social care services providers' dependency on subsidies provided out of the state budget). This may help create the necessary room for the expansion of all forms of provided home and community, outpatient and inpatient social care services.

One integral part of the social services development process as a whole in the coming period in consequence of demographic trends is the need for care providers to have the necessary trained personnel, especially when providing direct care.

Two alternative scenarios were opted for when estimating the expected impacts of population ageing on the need for social services in the period up to 2030 :

- the first scenario is based on the total number of persons of a given sex and age group accounted for by care allowance beneficiaries of that sex, age and degree of dependency and maintains this proportion for the entire period up to 2030 ;

- the second scenario is based on changes in the evolution of the share of care allowance beneficiaries by sex, age and degree of dependency in the total population of the given sex and age group between December 2016 and December 2011 and transposes this trend to the entire period up to 2030.

Whereas the first alternative is static, the second tries to factor in changes in the proportion of care allowance beneficiaries in the various groups in the years 2011-2016 so that the estimate of the expected impacts of population ageing on the need for social care services reacts to development trends in the period under scrutiny when the legal conditions and criteria for assessing the degree of dependency were stable. The number of care allowance beneficiaries is expected to 
rise from the present figure of just under 350,000 to $469,000-489,000$ by 2030 (see Table 2). Whereas the forecast for the number of care allowance beneficiaries in all degrees of dependency grows in the first scenario as a consequence of the increasing number of people of post-productive age, in the second scenario the expectation is that the number of first degree of dependency care allowance beneficiaries will fall by approx. 8,500 while the numbers of beneficiaries in the higher degrees of dependency will continue to rise, with the biggest increase expected in the $3^{\text {rd }}$ degree of dependency: the total number of beneficiaries of that social benefit is expected to rise from 80,700 persons in December 2016 to 147,200 in 2030 , i.e. by more than $80 \%$ (see Chart 2).

Table 2: Expected evolution of the number of care allowance beneficiaries by beneficiaries' age in the years 2016-2030

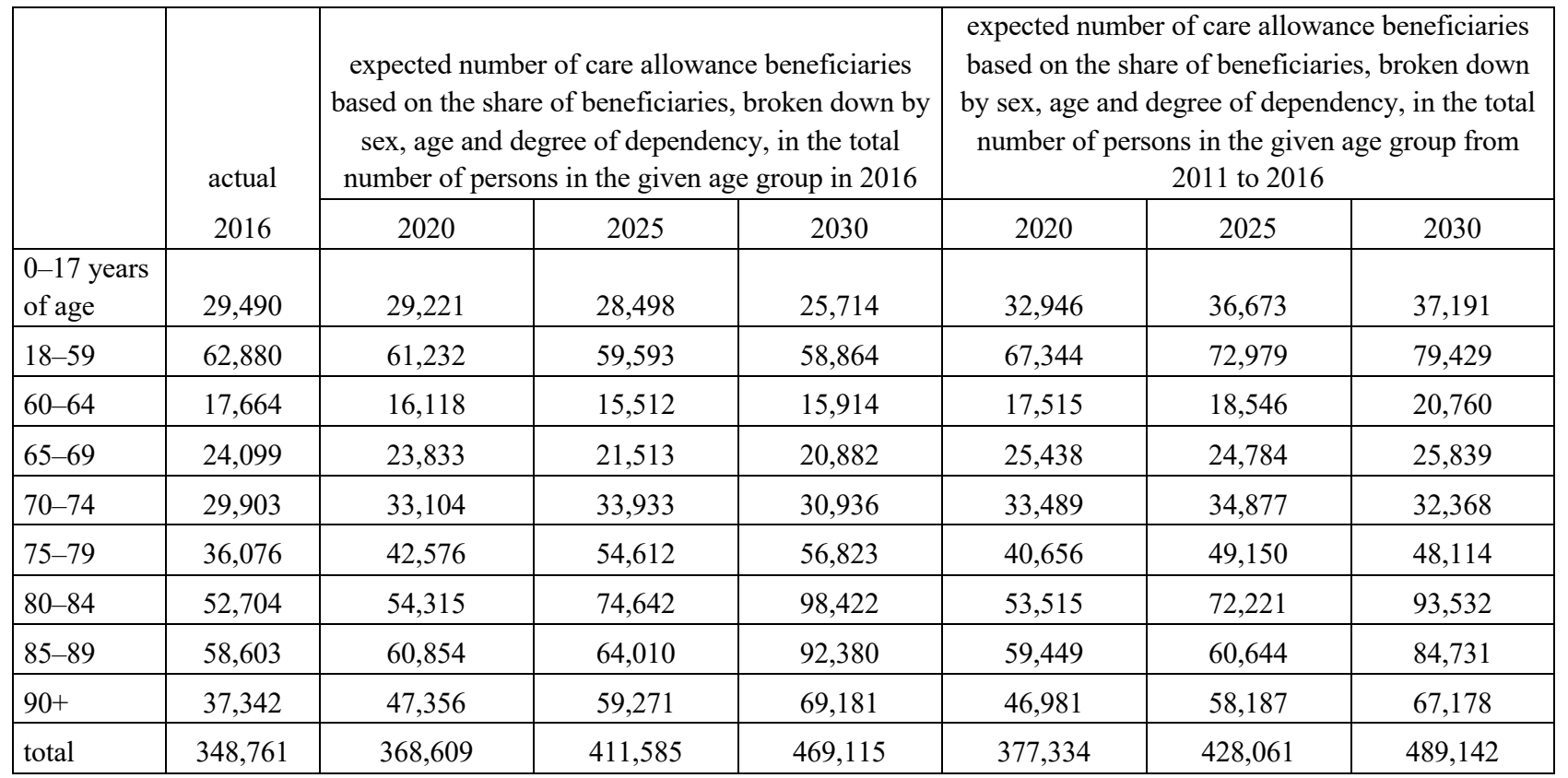

Source: own calculations

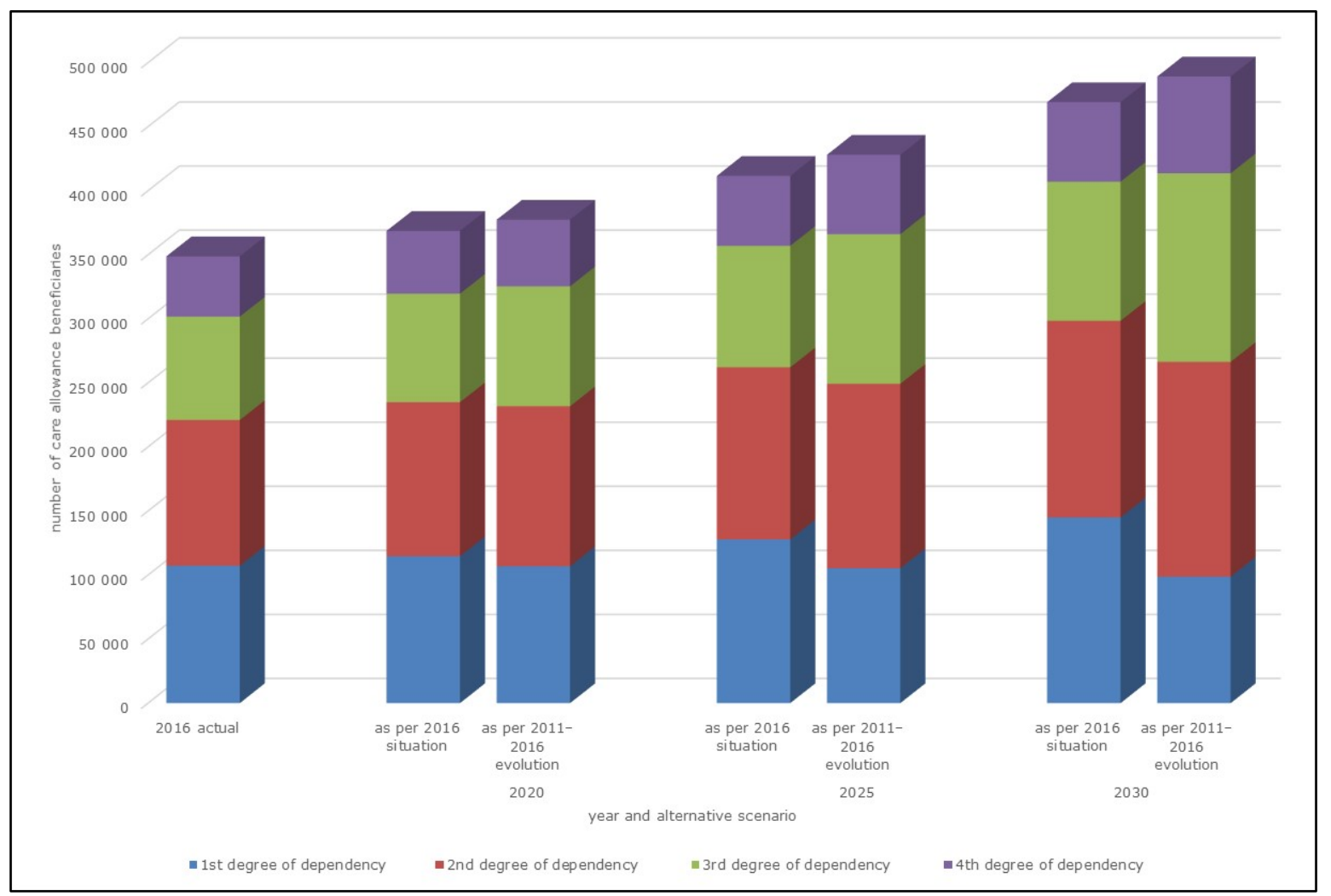


Figure 2: Estimated evolution of the number of care allowance beneficiaries up to 2030 (Source: own calculations)

Although it is reasonable to expect "objectivisation" of the structure of users of the various - mainly residential - social services facilities in the coming years, the presented calculations show that the existing capacities of the various types of facilities will not be sufficient in 2030. In this sense it is evident that the expansion of all forms of home and community, outpatient and inpatient facilities should become an integral part of all development plans at both municipal and regional level. One essential prerequisite making it possible to respond in time to the altered demographic situation is increasing the emphasis on analysing changes in the demographic situation in each region.

As a guideline, the following can be stated:

- the number of care allowance beneficiaries in the $1^{\text {st }}$ degree of dependency signals how many people will probably require assistance to cope with one or more of the care service actions in their own household, both through registered social services providers and through kith and kin or combined care;

- $\quad$ the number of care allowance beneficiaries in the $2^{\text {nd }}$ degree of dependency signals how many people will probably require more intensive assistance to cope with multiple care service actions in their own homes, in protected housing or in day services centres or day care centres, or possibly through kith and kin or combined care;

- the number of care allowance beneficiaries in the $3^{\text {rd }}$ degree of dependency signals how many people will probably require intensive, as a rule daily comprehensive care in old people's homes, in homes with a special regime, in homes for persons with a disability or in week care centres, and in extreme cases in protected housing or in their own homes, whereby a number of individuals will in these cases require personal assistance services and a sufficient extent of alleviation services should be available.

- $\quad$ the number of care allowance beneficiaries in the $4^{\text {th }}$ degree of dependency signals how many people will probably require intensive, comprehensive, all-day assistance in social services facilities (old people's homes, homes for persons with a disability, homes with a special regime), in healthcare facilities (sanatoria for the chronically ill, or possibly in social beds in inpatient healthcare facilities); only to a minimal degree can it be expected that such persons will receive care in other types of facilities or in their homes, but in these cases the majority will require personal assistance services and home healthcare, and a sufficient extent of alleviation services will also be required.

It is very difficult to specify precisely the exact extent of the provision of the various social services, because that is influenced by a whole series of factors determining their evolution in each region. It is therefore essential in this regard when drawing up medium-term social services development plans in cities and regions to perform a very detailed analysis of all the factors influencing the behaviour of clients and potential clients of the various types and forms of social services (Průša, 2015).

\subsection{Expected Impacts of Population Ageing on the Evolution of Health Insurance Companies' Expenditure on Healthcare Provision}

The most comprehensive tool making it possible to track the evolution of healthcare costs is the health accounts system. The Czech Statistical Office first drew up health accounts for the year 2000, working mainly on the basis of administrative sources of data kept by health insurance companies, commercial insurance companies and the Ministry of Finance of the Czech Republic (MoF). According to this system, total spending on healthcare amounted to CZK 353.7 billion in 2015; spending increased by approx. $3.8 \%$ from 2010, with the biggest volume of spending falling to health insurance companies $(66.4 \%$ of all healthcare expenditure in 2015$)$.

It is very difficult to assess the evolution of healthcare spending over the longer term, as the methodology for monitoring healthcare spending changed in the past: in 2014 there was a switch from the initial health accounts methodology to a higher development level, in which healthcare spending encompasses certain other data, most notably data from the field of prevention and long-term social care, with spending on certain social benefits (e.g. the care allowance) being included among healthcare costs.

Table 3: Evolution of healthcare spending from 2010 to 2014 (CZK million) 
Ladislav Průša

Impacts of an Ageing Population on Social Systems - Selected Issues

\begin{tabular}{|c|c|c|c|c|c|c|c|}
\hline system & 2010 & 2011 & 2012 & 2013 & 2014 & 2015 & $\begin{array}{c}2015 / 2010 \\
\text { increase }(\%)\end{array}$ \\
\hline $\begin{array}{l}\text { 1. government systems and compulsory } \\
\text { contributory systems of healthcare (public } \\
\text { funds) }\end{array}$ & 288,768 & 291,272 & 294,861 & 297,412 & 296,641 & 299,362 & 103.67 \\
\hline 1.1. government systems (public budgets) & 56,879 & 56,935 & 56,934 & 59,058 & 62,039 & 64,656 & 113.67 \\
\hline 1.1.1. state budget & 48,835 & 47,692 & 47,079 & 49,360 & 52,546 & 54,889 & 112.40 \\
\hline 1.1.2. local budgets & 8,044 & 9,243 & 9,855 & 9,698 & 9,493 & 9,766 & 121.41 \\
\hline 1.2. health insurance companies & 231,889 & 234,337 & 237,927 & 238,354 & 234,602 & 234,706 & 101.21 \\
\hline $\begin{array}{l}\text { 2. system of voluntary payments for } \\
\text { healthcare (private funds without direct } \\
\text { payments by households) }\end{array}$ & 9,217 & 9,205 & 9,110 & 9,202 & 10,668 & 9,322 & 101.14 \\
\hline 2.1. private insurance & 427 & 477 & 520 & 475 & 537 & 478 & 111.94 \\
\hline 2.2. non-profit organisations & 7,888 & 7,820 & 7,719 & 7,726 & 7,757 & 7,929 & 100.52 \\
\hline 2.3. enterprises & 901 & 908 & 871 & 1,001 & 2,374 & 915 & 101.55 \\
\hline 3. households & 42,705 & 44,028 & 44,239 & 43,465 & 46,490 & 45,043 & 105.47 \\
\hline total & 340,690 & 344,506 & 348,210 & 350,079 & 353,799 & 353,727 & 103.83 \\
\hline
\end{tabular}

Source: Czech Statistical Office, 2017.

The key data from the point of view of the consequences of population ageing on the evolution of healthcare costs are data on the evolution of the average expenditure of health insurance companies on healthcare per insuree by age and sex. In general, it is fair to say that healthcare spending increases with age and that spending levels differ between age groups, as the same disease has a different effect, different treatment duration and in some cases various complications at different ages.

The biggest increases in healthcare spending between 2010 and 2015 were in men aged 65-69 (up 4.2\%) and women aged $0-4$ (up 16.1\%). The highest healthcare costs in both men and women are in the 85+ age group: for men the costs were CZK 65,975 in 2015, while for women they were approx. CZK 3,000 lower at CZK 63,088. Chart 3 shows the evolution of health insurance companies' spending on healthcare per male insuree by age.

The following facts need to be taken into account when estimating the evolution of health insurance companies' healthcare spending in the coming years:

- $\quad$ population ageing and the consequences of this trend;

- changes in the population's standard of health;

- $\quad$ the import of and advances in modern medical apparatus and development of new fields of medicine;

- $\quad$ evolution of the epidemiological situation;

- $\quad$ the quest for the optimum provision for social needs in humane, technical, technological and thus also economic terms;

- $\quad$ increased intertwining and coordination of social and healthcare services at regional level and possible changes in the way care for the old and the disabled is organised and structured (Průša, 2017).

There are various interactions between these factors and it is not possible to define precisely the intensity of the effect of each one. It is estimated that healthcare's impact on the population's health is at most $15-20 \%$, with the decisive share - around 80\% - comprising the impact of "non-healthcare" factors (the environment, lifestyle, working environment and genetic predisposition) (Krebs, 2015). 


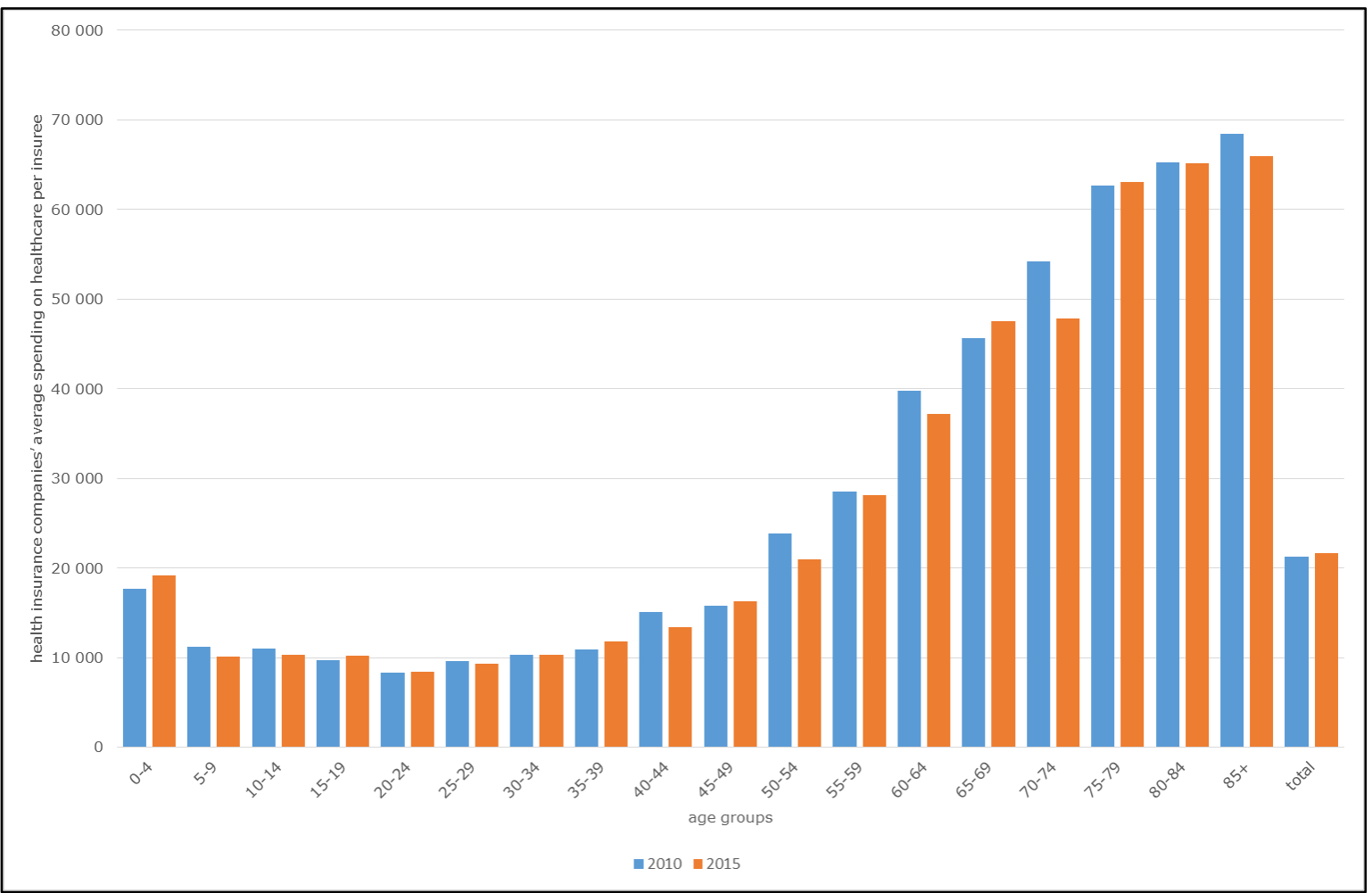

Figure 3: Evolution of health insurance companies' spending on healthcare per male insuree by age between 2010 and 2015 (CZK)

The estimate of the future evolution of health insurance companies' spending on healthcare was based on known data from the years 2000-2014. The values in the period under scrutiny matched the linear regression model closely, so it is reasonable to expect that the future growth (up to 2030) could also correspond to linear regression.

Table 4: Estimated evolution of health insurance companies' spending on healthcare per insuree by sex and age up to $2030(\mathrm{CZK})$

\begin{tabular}{|c|c|c|c|c|c|c|}
\hline age & 2020 & 2025 & 2030 & 2020 & 2025 & 2030 \\
\hline group & \multicolumn{3}{|c|}{ men } & \multicolumn{3}{|c|}{ women } \\
\hline $0-4$ & 22,184 & 25,015 & 27,845 & 19,346 & 21,813 & 24,279 \\
\hline $\begin{array}{l}5-9 \\
\end{array}$ & 13,187 & 15,000 & 16,813 & 10,981 & 12,373 & 13,764 \\
\hline $10-14$ & 13,185 & 15,086 & 16,986 & 13,922 & 16,084 & 18,246 \\
\hline $15-19$ & 12,237 & 14,037 & 15,837 & 15,333 & 17,662 & 19,991 \\
\hline $20-24$ & 10,054 & 11,429 & 12,803 & 13,748 & 15,481 & 17,214 \\
\hline $25-29$ & 11,627 & 13,327 & 15,027 & 18,535 & 21,030 & 23,525 \\
\hline $30-34$ & 12,816 & 14,707 & 16,598 & 21,503 & 24,844 & 28,185 \\
\hline $35-39$ & 13,952 & 15,942 & 17,931 & 19,482 & 22,302 & 25,121 \\
\hline $40-44$ & 16,773 & 19,121 & 21,468 & 20,218 & 22,932 & 25,646 \\
\hline $45-49$ & 17,699 & 19,561 & 21,423 & 22,881 & 25,608 & 28,335 \\
\hline $50-54$ & 25,668 & 28,590 & 31,513 & 28,044 & 31,349 & 34,654 \\
\hline $55-59$ & 34,810 & 38,912 & 43,013 & 31,340 & 35,039 & 38,737 \\
\hline $60-64$ & 48,319 & 55,166 & 62,013 & 36,792 & 41,214 & 45,637 \\
\hline $65-69$ & 61,089 & 72,540 & 82,135 & 47,229 & 53,437 & 59,645 \\
\hline $70-74$ & 72,642 & 83,236 & 93,831 & 57,484 & 65,293 & 73,102 \\
\hline $75-79$ & 81,481 & 93,668 & 105,854 & 65,765 & 75,082 & 84,398 \\
\hline $80-84$ & 84,922 & 97,979 & 111,037 & 71,135 & 81,316 & 91,497 \\
\hline $85+$ & 93,470 & 110,639 & 127,808 & 82,598 & 95,825 & 109,053 \\
\hline
\end{tabular}

Source: Průša, 2016

When transposing the presented estimates for the evolution of health insurance companies' healthcare expenditure into the Czech Statistical Office's demographic population forecast (intermediate scenario), it is reasonable to expect that 
there will be a sharp increase in these costs in the following years: health insurance companies' healthcare spending would reach CZK 314.0 billion in 2020, CZK 372.6 billion in 2025 and CZK 433.1 billion in 2030 (Průša, 2017). Compared to 2015, it is evident that the increase in health insurance companies' expenditure on healthcare will be pronounced, with an $84.5 \%$ increase to be expected by 2030 .

When estimating whether this spending increase can be financed out of health insurance premiums at the existing health insurance tariffs in the light of the expected changes in the population structure, it was necessary to try to quantify the expected evolution of the average and minimum wages, the expected evolution of the assessment base for the self-employed, the expected evolution of the structure of insurees (employees, self-employed, "state insurees") and the expected evolution of insurance premium rates for "state insurees". The estimate drawn up for the expected evolution of these parameters shows that, if the existing trends persist, the health insurance system can be expected to have run up a deficit of approx. CZK 27.6 billion as early as 2020; this deficit will then increase further, reaching CZK 47.9 billion in 2030 (see Chart 4) (Průša, 2017).

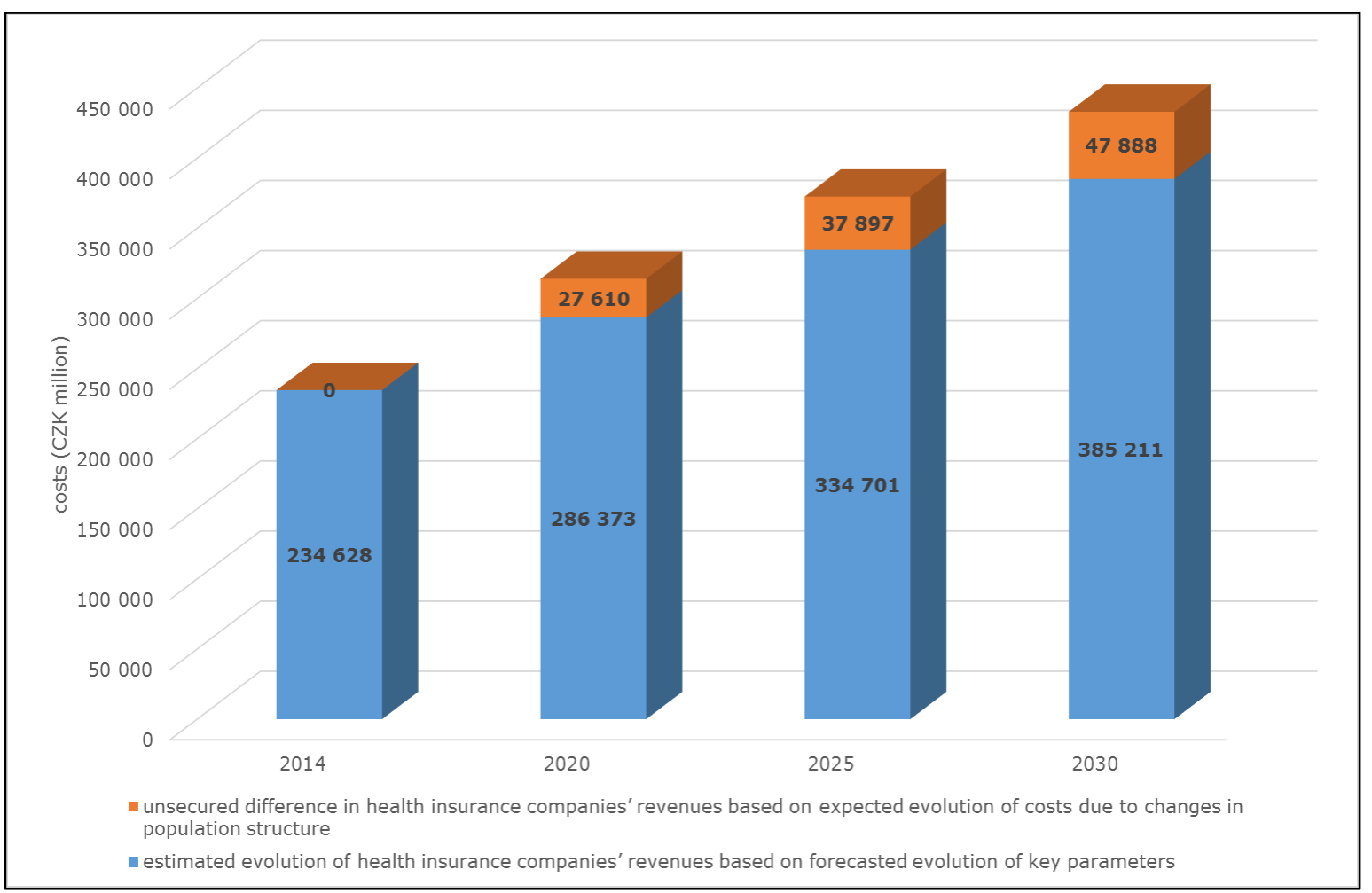

Figure 4: Estimated evolution of health insurance companies' spending on healthcare up to 2030

The chart shows that changes in the population's age structure mean that, if the existing legal state persists, the volume of healthcare insurance premiums collected can be expected to be lower than the expected volume of health insurance companies' expenditure on healthcare in the coming years, with this shortfall increasing every year. That makes it clear that new measures will have to be adopted in terms of both increasing health insurance companies' revenues and restricting their expenditure if health insurance companies are to break even. These measures might include the following:

- $\quad$ increasing health insurance premiums;

- a more pronounced increase in health insurance premium payments for "state insurees";

- $\quad$ increasing patients' participation in funding provided healthcare;

- $\quad$ looking for additional funding sources for healthcare;

- combinations of the above solutions.

These are altogether highly sensitive measures, which is evidence of the fact that our society is not yet prepared to tackle the consequences of population ageing. The simplest solution in technical terms, and one that would not require major legislative changes and would ensure that health insurance companies' expected spending on healthcare is financed out of the public health insurance system, would be a more pronounced increase in health insurance payments for "state 
insurees" than can be expected in the light of the evolution of these rates in the past. In 2020, for example, the expected level of this rate would have to rise from the originally estimated CZK 1,057 per month by CZK 368 to CZK 1,425; in 2025 the original rate of CZK 1,350 would have to increase monthly by CZK 504 to CZK 1,854; and in 2030 from CZK 1,723 to CZK 2,358 (up CZK 635).

Increasing the rates of health insurance premiums is another possible tool that could be used to help tackle the expected deficit in health insurance companies' funding of healthcare. For example, increasing health insurance premiums by $1 \%$ (from the current $13.5 \%$ to $14.5 \%$ ) would lead to an increase in health insurance companies' revenues from the health insurance system in 2020 from the estimated CZK 286,373 million by CZK 14,858 million to CZK 301,231 million. Despite this increase in health insurance companies' revenues, their expected expenditure on healthcare would still be CZK 12,572 million higher and there would have to be, for example, a further increase in the premiums for "state insurees" so that the health insurance companies' budgets as a whole are balanced (in this case the health insurance premium for "state insurees" would have to rise from the expected CZK 1,057 per month by CZK 170 to CZK 1,227). It should be kept in mind, however, that increasing health insurance premiums would increase the price of labour, which is already relatively high in the Czech Republic.

Increasing patients' participation in financing healthcare costs can be done using similar principles as were incorporated into the Czech health insurance system from 1 January 2008 in the form of "regulatory fees". Some of these fees were scrapped in the following years: currently, patients are only obliged to pay a regulatory fee of CZK 90 for the use of medical emergency services.

When looking for other sources of healthcare funding, inspiration can be taken from the Swiss pension insurance system, for example, where the state also participates in funding the first pillar (known as AHV insurance) - since 1 January 1999 the state has contributed part of value added tax to this system (Průša - Horecký, 2012). It is reasonable to believe that an equivalent solution could be applied to healthcare financing in the Czech Republic. Implementing this solution would evidently necessitate a general overhaul of the tax system and social and health insurance system, however (Průša, 2017).

\section{Conclusion}

The demographic forecast drawn up by the Czech Statistical Office in 2013 makes it possible to quantify the impacts of demographic change on all social systems. In the social services, this is all the more relevant because the expected changes in the population structure will have a pronounced impact on the need for care for the oldest population age group, as the proportion of over-65s in the population will increase sharply in the near future.

It is evident that the existing structure of social care services is not prepared for these changes. The calculations done identify an increased need for care in all age groups over 70: it is expected that the care allowance will be received by approx. 469,000-489,000 people in 2030, i.e. approx. 40\% more than in 2016, with the biggest increase to be expected in the $4^{\text {th }}$ degree of dependency (it is expected that the care allowance in this degree of dependency will be received by as many as 75,500 people in 2030 , i.e. approx. $60 \%$ more than in 2016). This makes it necessary to pay greater attention to increasing the effectiveness of the financing and provision of social services: it is necessary to fundamentally reassess the existing financing rules, with attention having to be paid to the staffing of the necessary care.

The coming years will bring a marked increase in health insurance companies' spending on healthcare: this spending can be expected to reach CZK 433.1 billion in 2030, an increase of $84.5 \%$ over the level in 2015. Based on the estimated evolution of the key parameters influencing the level of health insurance companies' revenues, expected revenues from the public health insurance system were then identified: it became clear that these revenues will be significantly lower than health insurance companies' expected spending on healthcare, with a revenues shortfall of approx. CZK 27 billion to be expected as early as in 2020. In the coming years it will therefore be necessary to look for additional sources of financing for healthcare so that its standard can be maintained at the current level. These measures can take the form of a more pronounced increase in health insurance premium payments for "state insurees"; higher health insurance premiums; increased patient participation in financing the provided healthcare; looking for additional sources of healthcare funding; or a combination of these solutions. 
Forecasting the need for social care services and the evolution of healthcare spending cannot be a one-off activity: it should become a regularly repeated project undertaken at all levels of public administration, for it is at the level of cities and municipalities that the currently changing conditions and needs of the population have to be responded to. Regrettably, however, minimal attention is being paid to matters of demographic development analysis in social services planning, for example.

\section{References}

- Czech Statistical Office (2013). Projekce obyvatelstva České republiky do roku 2100. [online]. Accessible at: https://www.czso.cz/csu/czso/projekce-obyvatelstva-ceske-republiky-do-roku-2100-n-fu4s64b8h4

- Czech Statistical Office (2017). Výsledky zdravotnických účtů ČR - 2010-2015 [online]. Accessible at: https://www.czso.cz/csu/czso/vysledky-zdravotnickych-uctu-cr-2016

- KREBS, V. and coll. 2015. Sociální politika. Prague: Wolters Kluwer, 2015. ISBN 978-80-7478-921-2.

- PRŮŠA, L. (1996). Sociální politika a determinanty jejího vývoje. Sociální politika no. 1/1996. ISSN 0049-0961.

- PRŮŠA, L. - HORECKÝ J. (2012). Poskytování služeb sociální péče pro seniory v České republice a ve Švýcarsku: mezinárodní komparace. Tábor: Asociace poskytovatelů sociálních služeb České republiky, 2012. ISBN 97880-904668-3-8.

- PRŮŠA, L. (2015). Důsledky stárnutí populace na potřebu služeb sociální péče. Demografie č. 3/2015. ISSN 00118265

- PRŮŠA, L. (2017). Důsledky změn věkové struktury obyvatelstva na vývoj nákladů na poskytování zdravotní péče. Demografie no. 1/2017, ISSN 0011-8265 